\title{
Efficacy of Fungicides Against Rhizoctonia solani Inciting Rhizome Rot Diseases on Large Cardamom (Amomum subulatum Roxb.)
}

\author{
Ajaya Karkee ${ }^{*}$, Dhanik L. Mandal ${ }^{2}$ \\ ${ }^{1}$ National Agriculture Genetic Resource Centre, Khumaltar, Lalitpur \\ ${ }^{2}$ Agricultural Research Station, Pakhribas, Dhankuta
}

\author{
Article Information \\ Received: 11 January 2020 \\ Revised version received: 14 March 2020 \\ Accepted: 17 March 2020 \\ Published: 29 March 2020 \\ Cite this article as: \\ A. Karkee and D.L. Mandal (2020) Int. J. Appl. Sci \\ Biotechnol. Vol 8(1): 61-64. \\ DOI: $\underline{10.3126 / \text { ijasbt.v8i1.27240 }}$

\section{*Corresponding author} \\ Ajaya Karkee, \\ National Agriculture Genetic Resource Centre, \\ Khumaltar, Lalitpur, Nepal \\ Email: ajayakarkee@gmail.com \\ Peer reviewed under authority of IJASBT \\ (C) 2020 International Journal of Applied Sciences and \\ Biotechnology
}

\section{OPEN}

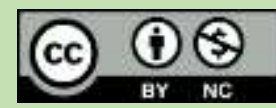

This is an open access article $\&$ it is licensed under a Creative Commons Attribution Non-Commercial 4.0 International (https://creativecommons.org/licenses/by-nc/4.0/)

Keywords: In vitro evaluation; mycelial growth; Rhizoctonia solani

\begin{abstract}
An in-vitro experiment was carried out for testing the efficacy of various fungicides by adopting poisoned bait method against Rhizoctonia solani (isolated from large cardamom) in Agricultural Research Station, Pakhribas. The experiments were conducted with Completely Randomized Design (CRD) during 2016 with four replications. Two level of concentration of the fungicides (10 ppm and $100 \mathrm{ppm}$ ) were used and concentration was calculated based on active ingredients (a.i.) of the pesticides. At lower concentration (10 ppm), Nativo (Tubeconazole 50\% + Trifloxystrobin $25 \mathrm{WG)} \mathrm{and} \mathrm{Dhanustan}$ (Carbendazim 50\% WP) whereas at higher concentration (100 ppm), Folicure (Tubeconazole $25.9 \%$ ) and Saaf (Carbendazim $12 \%+$ Mancozeb $63 \%$ WP) found effective for the inhibitions of mycelia growth of $R$. solani. For the control of $R$. solani, Nativo and Dhanustan showed greatest inhibition of mycelia growth at $10 \mathrm{ppm}$ concentration as compared to other fungicides. The fungicides containing Tubeconazole and Carbendazim as active ingredients, shows highest degree of mycelia inhibitions as compared to others. The fungicides found effective for inhibition of mycelia growth of $R$. solani in this study should be further tested in field conditions to verify their efficacy as well as to determine their optimum doses of application.
\end{abstract}

\section{Introduction}

Large cardamom (Amomum subulatum Roxb.) is commercially cultivated in Nepal and India (Belbase et al., 2018) and it is the high value cash crop and main source of income for the farmers of eastern himalayan region (Belbase et al., 2018). It is known as, Alaichi in Nepali and Badi Alaichi in Hindi and renounced as black cardamom, black gold, and queen of spices (Shrestha, 2018). It is grown in Nepal between an elevation of 600 to 2000 meter above sea level (masl) where annual rainfall is between 1,500 to
$2,500 \mathrm{~mm}$ and the temperature varies from $8^{\circ} \mathrm{C}$ to $20^{\circ} \mathrm{C}$ (Paudel et al., 2018). Diseases and insects are major problem in large cardamom production; rhizome rot is most frequently reported disease in large cardamom orchards (Yadav et al., 2015; Mahato et al., 2009). Rhizoctonia solani is caused rhizome rot diseases on large cardamom (Belbase et al., 2018). 
Rhizoctonia solani is a soil borne pathogen having a wide host range including vegetables, cereals, legumes and ornamental (Garcia et al., 2006). It is a basidiomycete fungus which does not produce asexual spores (Manandhar et al., 2018). The pathogen produces dark brown sclerotia which are the survival structures of the pathogen and can persist in soils for long periods of time (Agrios, 2005). The fungus is usually recovered from soils all over the world and is considered as a very destructive plant pathogen, with a broad host range, and causes diseases in a great variety of crops, including agronomical, ornamental and forestry species (Anderson, 1982; Sneh et al., 1991). Depending on the affected host, it causes symptoms like root rot, collar rot, damping off, wire stem, web blight and sheath blight (Garcia et al., 2006). Hence for searching the management of $R$. solani, an in-vitro assay of several fungicides was carried out at plant pathology lab of Agricultural Research Station, Pakhribas, Dhankuta.

\section{Materials and Methods}

\section{Experimental Materials and Research Design}

The in-vitro experiments were conducted at Agricultural Research Station, Pakhribas with Completely Randomized Design (CRD) during 2016 to test the efficacy of different fungicides (Table 1) against Rhizoctonia solani pathogen which cause rhizome rot diseases on Large cardamom.

\section{Isolation and culture of $R$. solani}

For obtaining pure culture of the pathogen, diseased rhizomes of large cardamom were cut into one $\mathrm{cm}$ sections which were surface sterilized using $1 \%$ sodium hypochlorate for one minute and rinsed with sterile water. After drying the tissues inside laminar flow, they were placed on water agar and incubated at $25^{\circ} \mathrm{C}$ for two days and hyphal tip culture was done on PDA plates under aseptic conditions. The plates were incubated at $25^{\circ} \mathrm{C}$ for one week until full growth of the pathogen.

\section{In vitro efficacy of fungicides on mycelia growth of $R$.} solani

Fungicides were evaluated for their efficacy to inhibit the mycelium growth of $R$. solani isolates by poisoned food technique (Schimitz, 1930). Ten fungicides (Table 2) were used at concentration of $10 \mathrm{ppm}$ and $100 \mathrm{ppm}$. Concentration (PPM) of the fungicide was calculated based on active ingredients (ai) of the pesticide provided by the company on each packet (Table 2). Stock solution of each fungicide was prepared in distilled water and incorporated into Potato dextrose agar medium and mixed thoroughly before autoclaving. After autoclaving the medium was poured aseptically in sterilized petri plates of $9 \mathrm{~cm}$ size in inoculation chamber and allowed to cool. Mycelial plugs of the pathogens $(5 \mathrm{~mm})$ taken from a seven days old culture was placed at the centre of each petri plate and incubated at $27^{\circ} \mathrm{C}$. PDA without with water or without chemical served as control.

Five mm circular discs of pathogen Rhizoctonia solani, were excised with sterile cork borer from one-week old culture and placed at the centre of PDA plates. Four petri dishes were chosen as four replications for each treatment and the experiment was arranged in complete randomized design (CRD). The plates were incubated at $25^{\circ} \mathrm{C}$ inside BOD incubator. Measurement of the colony diameter of pathogens was taken 10 days and 15 days after transfer with the help of measuring scale. Percent growth inhibition of the pathogen was calculated by using the following formula of Vincent (1947).

$\mathrm{I}(\%)=\frac{\mathrm{C}-\mathrm{T}}{\mathrm{C}} \times 100$

Where, I= inhibition percentage

$\mathrm{C}=$ Colony diameter in control

$\mathrm{T}=$ Colony diameter in treatment

Table 1: Treatments with Agrochemicals and their concentration used in the study

\begin{tabular}{llllll}
\hline S.N. & Commercial & Common Name & $\begin{array}{l}\text { Active ingredients } \\
(\mathbf{a i})\end{array}$ & $\begin{array}{l}\text { 100 ppm } \\
(\mathbf{m g})\end{array}$ & $\begin{array}{l}\text { 10 ppm } \\
(\mathbf{m g})\end{array}$ \\
\hline 1 & Antracol & Propineb 70 \% WP & 70.0 & 14.3 & 1.4 \\
2 & Sectin & Fenamidone 10 \%+ Mancozeb 50 \% WG & 60.0 & 16.7 & 1.7 \\
3 & Nativo & Tubeconazole 50 \%+Trifloxystrobin 25 WG & 75.0 & 13.3 & 1.3 \\
4 & Folicure & Tubeconazole 25.9\% & 25.9 & 38.6 & 3.9 \\
5 & Molodydue & Iprovalilcarb 5.5\%+Propineb 61.25 WP & 66.8 & 15.0 & 1.5 \\
6 & Dhanucop & Copperoxy chloride 50 \% wp & 50.0 & 20.0 & 2.0 \\
7 & Saaf & Carbendazim 12 \%+ Mancozeb 63 \% WP & 75.0 & 13.3 & 1.3 \\
8 & Dhanustan & Carbendazim 50 \% WP & 50.0 & 20.0 & 2.0 \\
9 & Relaxyl & Metalaxyl 8 \% + Mancozeb 64 \% WP & 72.0 & 13.9 & 1.4 \\
10 & Titan & Hexaconazole 5 EC & 5.0 & 200.0 & 20.0 \\
11 & Control & Water (Distilled) & 0.0 & 0.0 & 0.0 \\
\hline
\end{tabular}




\section{Statistical Analysis}

MSTAT-C statistical software package was used for the analysis of variance (ANOVA) to test the significance of treatment effect on mycelia growth of $R$. solani. Duncan's multiple range test (DMRT) was used to compare the values of significant treatment means at $1 \%$ level of significance.

\section{Results and Discussions}

All the tested fungicides exhibited control over the mycelia growth of the pathogen in varying degrees and they were significantly different from control at both concentrations i.e. at $10 \mathrm{ppm}$ and $100 \mathrm{ppm}$ (Table 2). Nativo, Folicure, Saaf and Dhanustan were individually effective against the pathogen by maximum inhibiting the mycelia growth. At lower concentration (10 ppm), Nativo and Dhanustan whereas at higher concentration (100 ppm), Folicure and Saaf completely inhibited the mycelia growth of $R$. solani. It was significantly superior over other fungicides and on par with each other. It was followed by folicure, Titan,
Antracol, Sectin, Saaf, Molodydue at lower concentration (10 ppm) and Molodydue and Relaxyl at higher concentration (100 ppm). Dhanucap and Relaxyl at lower concentration and Dhanucap at higher concentration were less effective and its value is on par with control. It was noted that as the concentration of fungicides increased, the mycelial inhibition is also increased. Hunjan et al. (2012) reported that fungicides viz., trifloxystrobin+ tebuconazole, tebuconazole and propiconazole showed higher level of efficacy against $R$. solani of rice in laboratory conditions. Among the new formulations, Nativo and Bavistin were individually effective against the pathogen in inhibiting the mycelia growth and sclerotial production at lower concentration (Sriraj et al. 2014). Tiwari et al. (2002) reported that propiconazole and hexaconazole at $1000 \mathrm{ppm}$ concentration completely inhibit the radial growth Rhizoctonia solani. Gupta (2002) also reported that carbendazim inhibited 95-100 per cent radial growth of Rhizoctonia solani.

Table 2: Colony diameter of Rhizoctonia solani at 10 PPM and 100 PPM after 10 and 15 days of transfer

\begin{tabular}{lllll}
\hline \multirow{2}{*}{ Fungicide } & \multicolumn{2}{l}{ Mycelial growth (Colony diameter) at 10 $\mathbf{~ p m}$} & \multicolumn{2}{c}{ Mycelial growth $($ Colony diameter) at 100 ppm } \\
\cline { 2 - 5 } & $\mathbf{1 0}$ days $(\mathbf{c m})$ & $\mathbf{1 5}$ days $(\mathbf{c m})$ & $\mathbf{1 0}$ days $(\mathbf{c m})$ & $\mathbf{1 5}$ days $(\mathbf{c m})$ \\
\hline Antracol & $2.90^{\mathrm{c}}$ & $3.53^{\mathrm{b}}$ & $2.80^{\mathrm{b}}$ & $3.06^{\mathrm{c}}$ \\
Sectin & $3.14^{\mathrm{bc}}$ & $3.48^{\mathrm{b}}$ & $2.03^{\mathrm{d}}$ & $2.53^{\mathrm{d}}$ \\
Nativo & $0^{\mathrm{f}}$ & $0^{\mathrm{d}}$ & $0^{\mathrm{e}}$ & $0^{\mathrm{e}}$ \\
Folicure & $0.63^{\mathrm{e}}$ & $1.01^{\mathrm{c}}$ & $0^{\mathrm{e}}$ & $0^{\mathrm{e}}$ \\
Molodydue & $3.90^{\mathrm{bc}}$ & $4.16^{\mathrm{b}}$ & $2.46^{\mathrm{c}}$ & $2.49^{\mathrm{d}}$ \\
Dhanucop & $5.42^{\mathrm{a}}$ & $5.49^{\mathrm{a}}$ & $3.39^{\mathrm{b}}$ & $4.16^{\mathrm{b}}$ \\
Saaf & $3.22^{\mathrm{bc}}$ & $3.66^{\mathrm{b}}$ & $0^{\mathrm{e}}$ & $0^{\mathrm{e}}$ \\
Dhanustan & $0^{\mathrm{f}}$ & $0^{\mathrm{d}}$ & $0^{\mathrm{e}}$ & $0^{\mathrm{e}}$ \\
Relaxyl & $4.37^{\mathrm{ab}}$ & $4.75^{\mathrm{ab}}$ & $3.31^{\mathrm{b}}$ & $4.05^{\mathrm{b}}$ \\
Titan & $1.29^{\mathrm{d}}$ & $1.46^{\mathrm{c}}$ & $0^{\mathrm{e}}$ & $0^{\mathrm{e}}$ \\
Control & $5.55^{\mathrm{a}}$ & $5.96^{\mathrm{a}}$ & $5.66^{\mathrm{a}}$ & $5.75^{\mathrm{a}}$ \\
\hline LSD & 0.31 & 0.29 & 0.11 & 0.12 \\
GM & 2.13 & 2.40 & 1.13 & 1.25 \\
F test & $* * *$ & $* * *$ & $* *$ & $* * *$ \\
CV & $6.3 \%$ & $4.5 \%$ & $4.1 \%$ & $7.3 \%$ \\
\hline
\end{tabular}

Table 3: Percentage of inhibition of Rhizoctonia solani at 10 PPM concentration of different fungicides

\begin{tabular}{lllll}
\hline \multirow{2}{*}{ Fungicide } & \multicolumn{2}{l}{ Percentage inhibition at 10 $\mathbf{~ p m}$} & \multicolumn{2}{c}{ Percentage inhibition at 100 ppm } \\
\cline { 2 - 5 } & after 10 days & after $\mathbf{1 5}$ days & after 10 days & after 15 days \\
\hline Antracol & 47.8 & 40.8 & 50.5 & 46.8 \\
Sectin & 43.4 & 41.6 & 64.0 & 56.0 \\
Nativo & 100.0 & 100.0 & 100.0 & 100.0 \\
Folicure & 88.7 & 83.1 & 100.0 & 100.0 \\
Molodydue & 29.7 & 30.2 & 56.0 & 56.7 \\
Dhanucop & 2.3 & 7.9 & 40.0 & 27.7 \\
Saaf & 42.0 & 38.6 & 100.0 & 100.0 \\
Dhanustan & 100.0 & 100.0 & 100.0 & 100.0 \\
Relaxyl & 21.3 & 20.3 & 41.5 & 29.6 \\
Titan & 76.8 & 75.5 & 100.0 & 100.0 \\
Control & 0.0 & 0.0 & 0.0 & 0.0 \\
\hline
\end{tabular}


For the control of $R$. solani, Nativo and Dhanustan showed greatest inhibition percent $(100 \%)$ of mycelia growth at 10 ppm concentration as compared to other fungicides whereas the concentrations increased to $100 \mathrm{ppm}$, Folicure and Saaf also showed $100 \%$ inhibition of the pathogen (Table 3). The fungicides containing Tubeconazole and Carbendazim as active ingredients, shows highest degree of mycelia inhibitions as compared to others. The inhibitory effect of Carbendazim on $R$. solani has also been reported by Kumar et al (2017). Kadri and Kanzari (2018) also reported that carbendazim 50\% WP and tebuconazole $25.9 \%$ EC among systemic fungicides gave maximum mycelial growth inhibition of 83.83 and 81.70 percent, respectively under laboratory conditions (Kadri and Kanzari, 2018).

\section{Conclusions}

In the present study, several fungicides showed as effective control agents against $R$. solani, though their efficacy varied among fungicides. These findings need further verification by application of these treatments in infected host plants and to find out the degree of control over the pathogen in vivo conditions.

\section{Author's Contribution}

A. Karkee designed the research plan; A. Karkee and D.N. Mandal performed experimental works and collected the required data. A. Karkee analyzed the data, prepared and finalized the manuscript. Final form of manuscript was approved by both authors.

\section{Conflict of Interest}

The authors declare that there is no conflict of interest with present publication.

\section{Acknowledgements}

We would like to thank Nepal Agricultural Research Council for providing the resource, Agricultural Research Station (ARS), Pakhribas for providing necessary support during this experiments and support staff of Agricultural Research Station, Pakhribas, Dhankuta for their valuable contribution to carry out this experiment at the lab.

\section{References}

Agrios GN (2005) Plant pathology $5^{\text {th }}$ edition. Root and stem rots caused by basidiomycetes. Elsevier Academic Press USA pp 593-599.

Belbase S, Paudel J, Bhusal R, Gautam S, Aryal A and Kumar S (2018) Fungal Diseases of Large Cardamom (Amomum subulatum Roxb.) and its Integrated Management. International Journal of Current Microbiology and Applied Sciences 7(3): 3316-3321. DOI: $\underline{10.20546 / \mathrm{ijcmas} .2018 .703 .382}$
Garcia VG, Onco MAP and Susan VR (2006) Review Biology nd systematic of the form genus Rhizoctonia. Spanish Journal of Agricultural Reserch 4(1): 55-79.

Gupta RP (2002) Fungicidal management of web blight of mungbean. Journal of Mycology and Plant Pathology 32 (1): 141-145

Hunjan MS, Love JS, Pannu PPS andThind TS (2011) Performance of some new fungicides against sheath blight and brown spot of rice. Plant Diseases Research 26: 6167.

Kadri NI and Kanzari KK (2018) In vitro efficacy of non-systemic and systemic fungicides against Rhizoctonia solani kühn causing root rot of coriander. International Journal of Chemical Studies 6(1): 1992-1995.

Kumar V, Chaudhary VP, Kumar D, Kumar S, Sagar S and Chaudhary S (2017) Efficacy of botanicals and fungicides against Rhizoctonia solani inciting sheath blight disease on Rice (Oryza sativa L.). Journal of Applied and Natural Science 9 (4): 1916 -1920. DOI: 10.31018/jans.v9i4.1463

Mahato BN, Yadav PK and Karna PL (2009) Disease Status of Commercial Crops and Future Strategies. In Acharya UK, Adhikari NP, Sherchan DP, Yadav PK and Karki KB (eds). Proceeding of the Second National Workshop on Commercial Crops, 14-15 November, 2005 held at National Agriculture Research Institute (NARI), Khumaltar, Lalitpur.

Manandhar S, Karkee A, Manandhar C, Pant B and Baidya S (2018) In vitro efficacy of different botanicals for the control of Alternaia alternate and Rhizoctonia solani. The journal of agriculture and environment 19: 92-97.

Paudel J, Belbase S, Gautam S and Bhusal R (2018) Viral Diseases of Large Cardamom their effect on Production and their Management. International Journal of Research Studies in Agricultural Sciences 4 (2): 21-26.

Shrestha KP (2018) Profitability of large cardamom enterprise in Nepal: Evidence from financial analysis. Journal of Agriculture and Natural Resources 1(1): 76-89. DOI: 10.3126/janr.v1i1.22224

Sriraj P, Sundravadana P, Adhipathi S and Alice D (2014) Efficacy of fungicides, botanicals and bioagents against Rhizoctoniasolani inciting leaf blight on turmeric (Curcuma longa L.). African Journal of Microbiology $\begin{array}{lll}\text { Research } & \text { 8(36): } & \text { 3284-3294. }\end{array}$ 10.5897/AJMR2013.6315

Tiwari RKS, Chandravanshi SS, Ojha BM and Thakur BS (2002) In vitro and In vivo Efficacy of rice. Journal of Mycology and Plant Pathology 32(3):418.

Vincent JM. 1947. Distortion of fungal hyphae in the presence of certain inhibitors. Nature 159(4051): 850. DOI: 10.1038/159850b0

Yadav PK, Chaudhary R, Shrestha S and Shrestha KP (2015) Farmers' Perception on Disease and Insect Incidences in Large Cardamom: A case Study of Mechi Zone, Nepal. In: Bhandari D and S Piya (eds), Proceeding of the $11^{\text {th }}$ National Outreach Research Workshop, 9-10 June, 2014, Outreach Research Division, NARC, Khumaltar. 